Check for updates

1 Imperial College Healthcare NHS Trust, London, UK

2 Faculty of Public Health and Policy, London School of Hygiene and Tropical Medicine, London, UK

Correspondence to: S Shanks sshanks@nhs.net

Cite this as: BMJ 2020;370:m3085 http://dx.doi.org/10.1136/bmj.m3085

Published: 06 August 2020

\title{
Covid-19 exposes the UK's broken food system
}

\author{
A proposed agriculture bill fails to fix it \\ Sarah Shanks, ${ }^{1}$ May Cl van Schalkwyk, ${ }^{2}$ Martin McKee $^{2}$
}

The SARS-CoV-2 pandemic has exposed fundamental weaknesses in UK society. Some fragile systems, such as social care, remained in the spotlight as the pandemic developed, but others attracted only fleeting attention-including the food system. ${ }^{1}$

Obesity, driven to a considerable extent by a food system that encourages consumption of cheap, energy dense products, quickly emerged as a leading risk factor for covid-19 mortality, ${ }^{2}$ but this was not the only interaction between food and covid-19. The early stages of the pandemic saw empty supermarket shelves and rationing of basic commodities. Closure of schools and loss of free school meals left many already disadvantaged children facing severe food insecurity.

The UK's food supply is fragile at the best of times. The country imports $47 \%$ of its food, including $84 \%$ of its fresh fruit, ${ }^{3}$ and depends critically on a just-in-time supply chain, with little capacity to withstand shocks. ${ }^{4}$ The Agriculture Bill 2019-21, the first new legislation on food and farming since exiting the European Union, is passing through parliament ${ }^{5}$ and has been described by the government as a "once in a generation opportunity" to reform farming and food supply. Comprehensive agricultural reform combined with a package of measures to support economic recovery after the pandemic would help the UK government deliver its commitment to build back stronger and greener, protect the NHS, and tackle obesity. But as it stands, the bill misses the mark.

The need to control obesity in the UK has become particularly urgent as further waves of covid-19 threaten the population and the NHS, while politicians scramble to compensate for years of slow progress with a new obesity strategy. ${ }^{6}$ Although some important policies are proposed-such as advertising restrictions on unhealthy foods-critical gaps in the agriculture bill could weaken public health for decades to come.

Agriculture policy shapes the food environment and provides an opportunity to improve dietary intake, yet better public health is not an explicit objective of the bill. ${ }^{7}$ We know from Brexit planning that unequal food distribution and disruption in supply chains have a disproportionate effect on low income groups, ${ }^{8}$ yet the bill is silent on such issues, and calls to tackle food insecurity are ignored. ${ }^{9}$ The bill seems entirely divorced from policies proposed by a government commissioned panel developing a national food strategy. ${ }^{10}$

The agriculture bill recently attracted media attention when MPs voted against legislating to maintain EU environmental and animal welfare standards on food imports, paving the way for imports of chlorinated chicken and hormone fed beef from the United States. But this narrow focus on food safety has diverted attention from unsustainable food production as a driver of antimicrobial resistance, emerging infectious diseases, climate change, and the consequences of poor farming standards on global health. ${ }^{11}$

Oversight of the food system is fragmented, with at least 16 government departments responsible for food as it moves from farm to fork in England. ${ }^{12}$ Never has the need for coordination been more evident, and action becomes even more urgent as the UK nears the end of the Brexit transition period. For almost half a century, the UK's food system has been shaped by EU policies on agriculture and trade, ${ }^{13}$ and the new bill proposes a wide ranging redesign of food production and farming. The government will also have to negotiate new trade deals with the EU and other nations, but little progress has been made and a "no deal" scenario, involving massive disruption to food supplies, seems likely.

When examining the link between food policy and health, attention is too often focused on influencing individuals' dietary choices. ${ }^{14}$ Insufficient attention has been paid to the food system as an "upstream determinant" of health. ${ }^{15}$ Covid-19 exposes weaknesses in public health and shows where radical transformation and prevention are needed-to promote population health and reduce the burden on health systems in both "normal" times and times of crisis.

Public health must change the discourse surrounding food systems bringing health, equity, and social justice to the centre of the debate and the evidence base. Healthcare professionals can advocate for health in all policy making to ensure that all sectors, and not just the NHS, work to promote health and resilience to future shocks. We can build back better post covid-19 but we must all help to lay a health-focused and equitable foundation. As it stands, the agriculture and food bill is a serious missed opportunity.

Provenance and peer review: Not commissioned, not peer reviewed

Competing interests: We have read and understood BMJ policy on declaration of interests and declare the following interests: Sarah Shanks and May CI van Schalkwyk have honorary contracts with Public Health England

Power M, Doherty B, Pybus K, Pickett K. How covid-19 has exposed inequalities in the UK food system: the case of UK food and poverty. Emerald Open Research2020;2:11doi: 10.35241/emeraldopenres.13539.2

2 Tan M, He FJ, MacGregor GA. Obesity and covid-19: the role of the food industry. BMJ2020;369:m2237. doi: 10.1136/bmi.m2237 pmid: 32522740

Department for Environment, Food, and Rural Affairs. Latest horticulture statistics. https://www.gov.uk/government/statistics/latest-horticulturestatistics 
4 Garnett P, Doherty B, Heron T. Vulnerability of the United Kingdom's food supply chains exposed by covid-19. Nature Food 2020;1:315-8doi: 10.1038/s43016-020-0097-7.

5 Agriculture Bill 2019-21.https://services.parliament.uk/Bills/2019-21/agriculture.html

6 Moore JB, Evans CEL. Obese and hungry: two faces of a nation. BM/2020;370:

7 Seferidi P, Laverty AA, Pearson-Stuttard J, etal. Impacts of Brexit on fruit and vegetable intake and cardiovascular disease in England: a modelling study. BMJ Open 2019;9:. doi: 10.1136/bmjopen-2018-026966 pmid: 30692079

8 van Schalkwyk MCl, Barlow P, Stuckler D, etal. Assessing the health effects of a "no deal" Brexit. BMJ 2019;366:15300. doi: 10.1136/bmj.l5300 pmid: 31466943

9 Written evidence submitted by the Independent Food Aid Network (AB59), 2019. https://publications.parliament.uk/pa/cm5801/cmpublic/Agriculture/memo/AB59.htm

10 National Food strategy. https://www. nationalfoodstrategy.org/

11 Machalaba CM, Karesh WB. Emerging infectious disease risk: shared drivers with environmental change. Rev Sci Tech 2017;36:435-44. doi: 10.20506/rst.36.2.2664 pmid: 30152473

12 Parsons K. Who makes food policy in England? A map of government actors and activities. Rethinking food governance 1. Food Research Collaboration. 2020.

https://foodresearch.org.uk/publications/who-makes-food-policy-in-england-and-food-policycoordination-under-covid19.

13 Benton T, Froggatt A, Wright G, Thompson CE, King R. Food politics and policies in post-Brexit Britain. Chatham House: London, UK. 2019 Jan. https://www.chathamhouse.org/publication/food politics-and-policies-post-brexit-britain/2019-01-10-BentonFroggattWrightThompsonKing.pdf

14 Bash K, Donnelly A. Sustainable food systems for a healthier UK: a discussion paper. Faculty of Public Health and The Soil Association. 2019. https://www.fph.org.uk/media/2409/sustainablefood-systems-for-a-healthier-uk-final.pdf

15 Jackson RJ, Minjares R, Naumoff KS, Shrimali BP, Martin LK. Agriculture policy is health policy. J Hunger Environ Nutr 2009:4:393-408. doi: 10.1080/19320240903321367 pmid: 23144677

This article is made freely available for use in accordance with BMJ's website terms and conditions for the duration of the covid-19 pandemic or until otherwise determined by BMJ. You may use, download and print the article for any lawful, non-commercial purpose (including text and data mining) provided that all copyright notices and trade marks are retained. 